Jurnal Konstruksi Hukum | ISSN: 2746-5055

Vol. 2, No. 2, Mei 2021, Hal. 401-405| Tersedia online di

https://www.ejournal.warmadewa.ac.id/index.php/jukonhum

DOI: https://doi.org/10.22225/jkh.2.2.3263.401-405

\title{
KEABSAHAN HASIL CETAK SCREENSHOT SEBAGAI ALAT BUKTI DALAM PEMERIKSAAN PERKARA PERDATA
}

\author{
I Gede Pastika Juniartha, I Nyoman Gede Sugiartha, Ni Made Puspasutari Ujianti \\ Fakultas Hukum Universitas Warmadewa, Denpasar-Bali, Indonesia \\ gedepastika90@gmail.com, nyomansugiartha14@gmail.com, puspa.niwapong@gmail.com
}

\begin{abstract}
Abstrak
Perkembangan teknologi komputer, telekomunikasi, dan informasi telah berjalan sedemikian rupa sehingga saat ini sudah sangat berbeda dengan 10 tahun lalu dengan perdagangan dan bisnis industri telah melahirkan model transaksi karena kemajuan dan keunggulan teknologi. Di zaman digital saat ini komputer, telekomunikasi, dan informasi berkembang sangatlah pesat menjadikan pemanfaatan teknologi tersebut mendorong pembuktian screenshot menjadi salah satu alat bukti yang digunakan di persidangan. Penelitian ini bertujuan untuk mengetahui pengaturan hukum atas alat bukti hasil cetak (screenshot) dalam sidang perkara perdata, dan untuk mengetahui kekuatan alat bukti hasil cetak (screenshot) dalam pembuktian perkara perdata. Metode penelitian yang digunakan yaitu penelitian hukum normatif dengan pendekatan perundang-undangan yang terkait dengan penelitian ini. Hasil penelitian menunjukkan bahwa pengaturan hukum alat bukti screenshot dapat dilihat dalam undang-undang No. 19 tahun 2016 dan Pasal 1866 KUHP yang biasanya digunakan di persidangan perkara perdata. Kemudian, kekuatan alat bukti screenshot mempunyai kekuatan pembuktian yang mengikat bagi hakim maupun para pihak terkait. Jadi, dapat disimpulkan bahwa alat bukti screenshot dapat digunakan dalam pemeriksaan perkara perdata karena posisinya sama dengan alat bukti lainnya serta dapat digunakan secara sah, dan alat bukti screenshot ini bersifat mengikat bagi hakim maupun bagi pihak lain yang hendak menggunakannya.
\end{abstract}

Kata kunci: Alat Bukti; Perkara Perdata; Screenshot.

\begin{abstract}
The development of computer, telecommunication and information technology has proceeded in such a way that is now has a very big difference from 10 years ago. Trade and industrial business have given rise to new transaction models due to advantages of technological advances. In today's digital age computers, telecommunications, and information are developing very rapidly, making the use of this technology encouraging proof of screenshots to be one of the evidence used in court. This study aims to determine the legal regulation of printed evidence (screenshots) in civil court proceedings, and to determine the strength of the printed evidence (screenshots) in proving civil cases. The research method used is normative legal research with a statutory approach related to this research. The results show that the legal regulation of screenshot evidence can be seen in Law No. 19 of 2016 and Article 1866 of the Criminal Code which is usually used in civil case trials. Then, the strength of the screenshot evidence has the power of proof that is binding for the judge and the parties concerned. So, it can be concluded that screenshot evidence can be used in civil case crossexamination because it is in the same position as other evidence and can be used legally, and this screenshot evidence is binding both for judges and for other parties who wish to use it.
\end{abstract}

Keywords: Evidence; Civil Cases; Screenshot.

\section{PENDAHULUAN}

Alat bukti dalam perkara sangat penting khususnya dalam pemeriksaan pengadilan perdata maupun pidana. Alat bukti ialah suatu alat selalu dipakai untuk menyatakan kenyataan yang dirujukan kepada si penggugat meskipun si tergugat daJam sidang perkara perdata, dalam Hukum Perdata alat bukti diatur dalam Pasal 1866 KUHP yang terdiri dari beberapa alat bukti yakni surat, saksi, persangkaan, pengakuan dan sumpah (Bukido, 2011). Dengan seiring perkembangan zaman alat bukti tidak bertumpu pada Pasal 1866 KUHP di mana sekarang terdapat alat bukti elektronik. Jadi alat bukti itu adalah sesuatu yang sebelum diajukan ke persidangan (Wiwie, 2013). Pernah dipersoalkan, jika di samping lima alat bukti yang terdapat pada Pasal 1866 KUHP (Kitab Undang-Undang Hukum Perdata) apakah tidak ada alat bukti lainnya. Persoalan tersebut sering dibahas pada pengucapan alatalat bukti pada pasal-pasal yang terkait tiada melarang adanya alat-alat bukti berlainan selain alat bukti pada Pasal 1866. Tidak tertutup kemungkinan pula untuk pengajuan alat bukti yang berupa 
prediksi-prediksi namun bukan tulisan (Sari, 2019). Berkembangnya budaya internet di Indonesia jadi prediksi-prediksi kemodernan bisnis dan sangat mempengaruhi rakyat global perkembangan internet memperlihatkan manfaat secara ekonomis, finansial, tenaga, lalu berbeda pada pertumbuhan global komunikasi dan informasi.

Meskipun dengan kemajuan teknologi yang sangat pesat, dibalik keuntungan-keuntungan dari kemajuan teknologi khususnya dibidang komunikasi bisnis via internet, di mana ada permasalahan hukum yang terdapat pada komunikasi bisnis via internet tersebut (Wibowo, 2014). Dengan kemajuan teknologi yang sangat pesat dalam beberapa tahun tampaklah seputar alat-alat atau teknologi segar serupa fotocopy, alat scan, tape recorder dan juga ponsel pintar pada biasa digunakan untuk melakukan bisnis dan transaksi melalui M-Banking yang sering digunakan untuk melakukan pembayaran di mana bukti dari pembayaran tersebut bisa di screenshot untuk membuktikan seseorang tersebut sudah melakukan pembayaran. Screenshot adalah sebuah gambar dan cuplikan layar yang diperoleh atau direkam yang terdapat pada alat elektronik dan ponsel pintar yang biasanya digunakan atau di tunjukan kepada orang lain. Dalam perdagangan elektronik melalui internet tidak selalu berjalan baik maupun mulus, pasti akan ada masalah-masalah hukum yang terjadi dalam perdagangan tersebut. Salah satunya seperti barang cacat, barang tidak sampai, hilang saat pengiriman, atau barang yang dikirim tidak sesuai dengan yang dipesan (Paryadi, 2018). Dengan demikian hal-hal tersebut akan sangat rnerugikan konsumen Untuk itu diperlukan perlindungan hukum terhadap hak-hak konsumen. Untuk menyatakan bahwa adanya kerugian yang diterima oleh konsumen maka dibutuhkan suatu alat bukti dalam perkara persidangan.

Berdasarkan pemaparan latar belakang masalah di atas, maka penelitian dirumuskan untuk mengetahui pengaturan hukum alat bukti hasil cetak (screenshot) dalam sidang perkara perdata, serta untuk mengetahui kekuatan alat bukti hasil cetak (screenshot) dalam pembuktian perkara perdata.

\section{METODE PENELITIAN}

Metode riset studi yang dipakai pada penelitian ini yaitu penelitian hukum normative (Soekanto \& Mamudji, 2006). Penelitian hukum normatif atau metode penelitian kepustakaan ialah metode yang dipakai di dalam penelitian hukum yang dilaksanakan dengan meneliti bahan pustaka yang ada, serta berkaitan dengan penerapan hukum sesuai dengan rumusan masalah yang dijadikan topik bahasan. Mengenai pendekatan masalah yang digunakan dalam penelitian ini, pendekatan perundang-undangan digunakan terkait dengan alat-alat bukti pada pemeriksaan perkara perdata yang diteliti. Pendekatan ini dapat dilakukan dengan mempelajari konsistensi/kesesuaian antara UUD dengan UU, atau antara undang-undang yang satu dengan undang-undang yang lainnya. Asal muasal materi aturan yang digunakan berasal dari studi tentang dalil-dalil normatif ini, sumber lain diperoleh pula dari riset kepustakaan pada bahan-bahan hukum yang lain. Adapun sumber bahan hukum tersebut yaitu bahan hukum primer, yaitu materi aturan yang diperoleh dari peraturan perundang-undangan yang berlaku. Bahan hukum primer ini mencakup Perppu, undang-undang aturan Perdata yakni UUD 1945, UU HIR (Herzien lnlandsch Reglement), undang-undang RBG (Rechtreglement voor de Buitengewesten), Kitab Undang-Undang Hukum Perdata UU No. 19 tahun 2016 tentang lnformasi dan Transaksi Elektronik. Kemudian, Lembaran Negara Republik Indonesia tahun 2016 Nomor 251, tambahan Lembaran Negara Republik Indonesia Nomor 5952. UU No. 48 tahun 2009 Tentang Kekuasaan Kehakiman, Lembaran Negara Republik Indonesia Tahun 2009 Nomor 157. Tambahan Lembaran Negara Republik Indonesia Nomor 5076. Sumber bahan hukum seterusnya adalah bahan hukum sekunder yakni bahan hukum yang diperoleh melalui penelitian kepustakaan, yang dapat berupa buku-buku, jurnal ilmiah, hasil penelitian ahli, media massa atau surat kabar dan juga sumber dari internet yang berkaitan dengan proses pembuktian di depan persidangan mengenai alat-alat bukti.

Teknik pengumpulan materi aturan riset studi hukum normatif dilakukan dengan mempelajari materi-materi hukum yang diperoleh melalui kepustakaan, maka teknik pengumpulan bahan hukum dilakukan dengan cara melakukan klasifikasi terhadap bahan-bahan hukum, melakukan pencatatan seluruh bahan hukum, membaca serta melakukan sistematika terhadap bahan-bahan hukum yang telah terkumpul yang berkaitan dengan permasalahan dalam penelitian ini serta berkenaan dengan penggunaan alat-alat bukti. Kemudian, analisis data dilakukan dengan analisis bahan hukum yang terkumpul dengan cara mencatat dan menganalisa. Analisa merupakan langkah selanjutnya untuk mengolah hasil penelitian menjadi suatu laporan yang kemudian dianalisis secara sistematis dengan menggunakan argumentasi hukum dan hasilnya kemudian disajikan secara deskriptif analisis. 
Penyajian data dibuat dalam bentuk siasat deskriptif analisis, yaitu suatu siasat analisis materi aturan yang dilaksanakan dengan membangun kalimat secara sistematis sehingga diperoleh sebuah simpulan yang tepat dan benar secara logis dan ilmiah.

\section{HASIL DAN PEMBAHASAN}

\section{Pengaturan Hukum Alat Bukti Hasil Cetak (screenshot) dalam Sidang Perkara Perdata}

Dalam hukum Perdata alat bukti diatur dalam Pasal 1866 KUHP yang terdiri dari beberapa alat bukti. Alat bukti ialah suatu barang yang digunakan untuk memperlihatkan kenyataan yang ditunjukkan kepada pihak penggugat maupun pihak tergugat dalam sidang perkara perdata, di mana alat bukti ini bertujuan untuk membuktikan sebuah kebenaran di dalam sidang perkara perdata. Dalam Pasal 1866 KUHP yang terdiri dari beberapa alat-alat bukti yaitu

a. Alat bukti surat. Surat maupun tulisan ialah alat bukti pada paling sentral berkat pada hukum keperdataan ibarat uang pinjaman, mengontrak-mengontrak lalu jual-beli, surat maupun tulisan ini dengan sengaja dibuat hendak memperlihatkan perilaku aturan seseorang pada ia lakukan pada akan datang kalaupun muncul sebuah permasalahan. Alat bukti surat dapat dibagi menjadi 2 (dua) bagian, yaitu surat berupa akta dan ada pula teks yang tidak berbentuk akta, sering disebut sebagai surat biasa. Sedangkan, akta dibagi menjadi 2 (dua) macam yaitu akta otentik dan akta di bawah tangan. Akta adalah surat yang memuat peristiwa yang menjadi dasar suatu hak atau perikatan.

1) Dalam alat bukti surat terdapat surat biasa, surat biasa dibuat bukan dengan arahan agar digunakan alat bukti. Akan demikian, andaikan di kemudian waktu surat itu digunakan alat bukti di persidangan, hal ini bersifat insidental (kebetulan) (Mulyadi, 2009).

2) Akta otentik adalah surat atau akta yang dengan terencana dibuat menurut legal bertujuan agar dibuatkan alat bukti pada pembuktian perdata pada akhimya jika kalau terjadi permasalahan hukum atau permasalahan.

3) Akta di bawah tangan ialah akta yang terencana dibuat bertujuan buat pemastian kepada para pihak yang mempunyai keperluan tanpa bantuan dari pejabat yang berwenang.

b. Alat bukti keterangan saksi. Keterangan saksi adalah kesaksian yang ditunjukkan kepada hakim di persidangan tentang suatu peristiwa yang sedang disengketakan dengan cara memberitahu secara langsung atau secara lisan oleh orang yang bukan salah satu pihak dalam perkara. Jadi keterangan yang diberikan oleh seorang saksi haruslah kejadian yang telah dialami sendiri (Asikin, 2015).

c. Alat bukti persangkaan. Persangkaan merupakan alat bukti yang sifatnya tidak langsung, karena alat bukti persangkaan tidak bisa berdiri sendiri namun harus dengan aJat bukti lain.

d. Alat bukti pengakuan. Pengakuan adalah suatu keterangan yang membenarkan suatu peristiwa hak atau hubungan hukum yang diajukan oleh pihak lawan. Dengan adanya pengakuan sengketa maupun permasaJahan hukum lainnya dianggap selesai sekalipun pengakuan yang diungkapkan tidak sesuai dengan kejadian atau kejujuran, dan hakim tak buruh meneliti jujuran tersebut.

e. Alat bukti sumpah. Alat bukti sumpah adalah suatu pernyataan yang diucapkan pada waktu memberikan sebuah janji dengan mengingat Tuhan Yang Maha Esa atau berjanji kepada Tuhan bahwa segala yang diucapkan adalah sebuah kebenaran tanpa adanya kebohongan.

Usaha pembuktian ialah indera yang di peruntukan di mana agar melakukan pembuktian terhadap dalil-dalil suatu individu di pengadilan, seperti halnya bukti tulisan, kesaksian, persangkaan, dan sumpah. Suatu alat bukti elektronik mempunyai kejujuran aruran andaikan informasi bisa menjamin kebenaran dari alat bukti tersebut dan juga dapat dipertanggungjawabkan, dapat diakses, dapat ditampilkan sehingga dapat menjelaskan kebenaran alat bukti tersebut. Seseorang yang mempunyai bukti elektronik atau mengajukan bukti elektronik mesti bisa atau dapat menjelaskan pada alat buktinya atau berita yang dimiliki berawal pada sistem elektronik berkeyakinan. Pada saat ini banyak masyarakat menggunakan transaksi online atau transaksi elektronik di mana transaksi tersebut lebih dikenal dengan nama Electronic Commerce atau disingkat e-commerce. E-commerce adalah kegiatan-kegiatan yang dilakukan untuk usaha yang membelit pembeli (consumers), manufaktur (manufacturers), service providers, dan pedagang perantara (intermediaties) dengan memanfaatkan internet atau hubungan-hubungan komputer (computer network). Pada terbitnya pengaturan tentang Dokumen Perusahaan bahwa dapat dibicarakan aturan Indonesia sudah mulai bukti elektronik (Fakhriah, 2017). 


\section{Kekuatan Alat Bukti Hasil Cetak (Screenshot) dalam Pembuktian Perkara Perdata}

Pembuktian adalah suatu prosedur untuk menyatakan kejujuran terhadap suatu hak atau peristiwa, yang terbentuk pada berbagai elemen dan diantaranya sama-sama terikat. Pada verifikasi mempunyai beberapa komponen seperti subjek pembuktian, objek pembuktian, asas-asas dalam pembuktian, alatalat bukti, kekuatan pembuktian, yang di dalamnya terjadi pada belahan antara satu beserta lainnya yang saling berhubungan. Pembuktian yakni merupakan masalah yang memegang peranan dalam proses pemeriksaan dalam sidang pengadilan, pembuktian yang diajukan oleh para pihak akan dinilai oleh ketua sidang. Pada kasus ini, pembuat UU bisa mengikat ketua sidang pada alat-alat bukti khusus adalah alat bukti surat, sampai-sampai ketua sidang tidak leluasa menilainya. Kekuatan pembuktian alat bukti surat bisa dilainkan menjadi akta dan bukan akta. Surat pada khususnya berwujudkan akta otentik dengan akta di bawah tangan. Akta otentik mempunyai kekuasaan pembenaran baik lahir, formal maupun materil. Akta otentik memiliki keistimewaan di mana keistimewaan ini terdapat pada kemampuan pembuktian lahir, pada arti formil akta otentik memastikan kejujuran berawal pada apa yang dilihat dan sebaliknya pada pembuktian materil tidak seluruh akta otentik yang berwujud akta pejabat memiliki kekuatan verifikasi materil, namun seluruh akta otentik dapat pula mempunyai kekuasaan verifikasi materiil. Selanjutnya akta di bawah tangan, apabila tandatangan yang terdapat di dalam sebuah akta pada bawah tangan diakui pada penandatangan pada akta tadi maka pemberitahuan yang terdapat pada akta tersebut tidak akan bisa dibantah, sehingga akta di bawah tangan tersebut mempunyai kekuatan bukti yang sempurna.

Alat bukti penjelasan saksi dalam kekuasaan verifikasinya yang diamanatkan kepada ketua sidang, pada makna memiliki kekuasaan verifikasi yang leluasa, sebab pada dapat tidaknya Penjelasan seorang saksi dibenarkan terkait pada banyak hal yang layak dipertimbangkan oleh ketua sidang. Dalam pertimbangan makna keterangan, ketua sidang sebaiknya mengawasi kesesuaian atau kesetujuan pada penjelasan para saksi. Kesesuaian pada penjelasan ini berdasar dari apa yang dimengerti dan berkenaan pada perkara yang dipermasalahkan. Alat bukti persangkaan, di mana kekuatan pembuktian bisa dibedakan menjadi persangkaan berdasarkan UU dengan persangkaan berlandaskan kebenaran. Persangkaan berdasarkan UU dimana kekuasaan verifikasinya berkarakter mengharuskan, sebaliknya persangkaan berlandaskan kebenaran (persangkaan ketua sidang) kekuasaan verifikasinya diamanatkan kepada pertimbangan ketua sidang (kekuatan pembuktian bebas).

Pembenaran menjadi alat bukti kekuasaan verifikasi pengakuan adalah bukti yang paripuma sehingga bisa juga bersifat memilih tidak memungkinkan verifikasi bagi yang melaksanakannya. Lebih lanjut dijelaskan bahwa pembenaran asli bukan pengakuan murni, bukan pengakuan dengan tambahan. Sumpah sebagai alat bukti dalam sumpah jadi alat bukti bisa dibagi menjadi 2 (dua) jenis sumpah ialah yang pertama sumpah penambah dan sumpah penaksir dalam sumpah ini bersifal final dan mutlak apabila tetap memperoleh verifikasi pembanding, padahal dalam sumpah pemutus kekuasaan verifikasi paripurna menjerat bagi ketua sidang bila tidak mendapat kemungkinan pada verifikasi musuh. Bersamaan dipublikasikannya sumpah pemurus maka kejujuran kejadian menjadi pasti dan pihak musuh tidak dapat memperlihatkan sebaliknya. Pengecekan setempat dan keterangan ahli walaupun keterangan ahli dan pemeriksaan setempat tidak dimuat atau termasuk dalam macammacam alat bukti namun tujuannya sebagai menaikkan kemampuan ketua sidang agar mendapat kejelasan terhadap kejadian yang dipermasalahkan maka hakikatnya adalah sebagai alat bukti. Kekuasaan verifikasinya, baik sumpah maupun keterangan ahli, diamanatkan pada pertimbangan ketua sidang yang memiliki kemampuan verifikasi yang paripurna. Bahkan mengenai aturan pun kerua sidang bisa memperoleh bantuan seorang ahli, seperti untuk mengetahui adat adat setempat kepala adat atau kepala suku didengar sebagai ahli (Mertokusumo, 2009).

\section{SIMPULAN DAN SARAN}

\section{Simpulan}

Berdasarkan pemaparan hasil penelitian diatas, maka dapat disimpulkan bahwa di dalam pengaturan hukum alat bukti hasil cetak (screenshot) dalam sidang perkara perdata mengenai alat bukti diatur dalam Pasal 1866 KUHP. Dengan adanya alat bukti elektronik dimana terdapat informasi berbentuk dokumen elektronik seperti penggunaan gambar atau yang lebih dikenal dengan nama screenshot, digunakan untuk menjadi bukti transaksi khususnya pembayaran melalui M-Banking. Jadi dengan kata lain screenshot tersebut sama dengan alat bukti surat yang digunakan untuk melakukan 
pembayaran atau bertransaksi dalam jual beli. Kemudian, mengenai kekuatan alat bukti hasil cetak screenshot dalam pembuktian perkara perdata di pengadilan, dimana alat bukti surat gambar tampilan monitor (screenshot) memiliki kekuatan pembuktian yang membelenggu bagi ketua sidang maupun para pihak. Screenshot juga termasuk dalam alat bukti elektronik yang juga mempengaruhi hakim dalam memeriksa dan memutus perkara yang diajukan terhadapnya di pengadilan.

\section{Saran}

Adapun saran yang hendak disampaikan berdasarkan simpulan di atas, meliputi saran bagi pemerintah; seiring berkembangnya zaman, pemerintah harus selalu memperhatikan transaksitransaksi online agar tidak ada penipuan yang merugikan masyarakat dan pemerintah juga dapat mengatasi perkara yang diajukan ke pengadilan. Saran bagi masyarakat mengenai penelitian ini yakni hendaknya masyarakat lebih memahami mengenai apa saja yang termasuk kedalam alat bukti yang terdapat dalam KUHP maupun alat bukti elektronik.

\section{DAFTAR PUSTAKA}

Asikin, H. Z. (2015). Hukum Acara Perdata di Indonesia. Jakarta: Prenadamedia Group.

Bukido, R. (2011). Kedudukan Alat Bukti Tulisan terhadap Penyelesaian Perkara di Pengadilan. Jurnal Ilmiah Al-Syir'ah, 9(1), 1-18.

Fakhriah, E. L. (2017). Bukti Elektronik dalam Sistem Pembuktian Perdata. Bandung: PT Refika Aditama.

Mertokusumo, S. (2009). Hukum Acara Perdata Indonesia. Yogyakarta: Cahaya Atma Pustaka.

Mulyadi, L. (2009). Putusan Hakim dalam Hukum Acara Perdata Indonesia: Teori, Praktik, Teknik Membuat, dan Permasalahannya. Bandung: PT Citra Aditya Bakti.

Paryadi, D. (2018). Pengawasan E Commerce Dalam Undang-Undang Perdagangan Dan UndangUndang Perlindungan Konsumen. Jurnal Hukum \& Pembangunan, 48(3), 651-669.

Sari, D. P. (2019). Kekuatan Pembuktian Fotokopi Surat yang Tidak Dapat Dicocokkan dengan Aslinya dalam Perkara Perdata. Undang: Jurnal Hukum, 2(2), 323-352.

Soekanto, S., \& Mamudji, S. (2006). Penelitian Hukum Normatif Tinjauan Singkat. Jakarta: Rajawali Pers.

Wibowo, E. A. (2014). Pemanfaatan Teknologi E-Commerce dalam Proses Bisnis. Equilibiria, 1(1), 95-108.

Wiwie, A. A. (2013). Asas-Asas Hukum Pembuktian Perdata. Jakarta: Kencana Penadamedia Group. 